\title{
PHENOTYPIC AND MOLECULAR CHARACTERIZATION OF MULTISHOOTS DEVELOPMENT IN TRANSGENIC Phalaenopsis amabilis (L.) BLUME HARBORING 35S::KNAT1 (KNOTTED-LIKE Arabidopsis thaliana 1)
}

\author{
TRIONO BAGUS SAPUTRO ${ }^{1}$, ENDANG SEMIARTI ${ }^{2 *}$ and AZIZ PURWANTORO ${ }^{3}$ \\ ${ }^{1}$ Departement of Biology, Institut Teknologi Sepulub Nopember, Surabaya 60111, Indonesia \\ ${ }^{2}$ Faculty of Biology, Universitas Gadjah Mada, Yogyakarta 55281, Indonesia \\ ${ }^{3}$ Faculty of Agriculture, Universitas Gadjah Mada, Yogyakarta 55281, Indonesia
}

Received 28 January 2017/Accepted 07 June 2017

\begin{abstract}
Phalaenopsis amabilis (L.) Blume is one of Indonesian natural orchid which has an aesthetic flower and possesses high economic value. The low multiplication rate and long periods of life cycle are the main obstacles to conventionally propagate this orchid. The aims of this research were to analyze the stability of transgenic plant $P$. amabilis harboring 35S::KNAT1 based on morpho-genomic characterization. KNAT1 gene is reported as a gene that involved in the shoot formation, and it had been successfully introduced into Phalaenopsis amabilis (L.) Blume genome. After seven times regeneration, the confirmation of the transgene existence in the genom is needed to ensure whether the plant could consistently maintain the transgene in its genome and to characterize the shoot development. The experiment was carried out in 3 steps: 1) Co-integration analysis of 35S::KNAT1 into P. amabilis genom;2) Phenotypic analysis on the multiplication rate, morphological variation and venation pattern; and 3) Protein profile analysis of transgenic plants. The results showed that the survival rate of putative transgenic was $58.7 \%$ on NP0 medium and $62.5 \%$ on NP SIM medium. PCR analysis confirmed that $82.5 \%$ transgenic growth on NP0 and $93.33 \%$ on NP SIM contained DNA fragment of KNAT1 gene, NPTII gene and trnL-F intergenic spacer, indicating that those plants are positive transgenic. The 35S::KNAT1 transgenes and phytohormone were independently involved in multishoots formation of $P$. amabilis transgenic plants. The phenotypic of plantlets were classified into six main criteria, i.e. normal shape, lobed leaves, rosette, elongated stem, cup shoot and widened leaves. The normal type was the most abundant type of variation $( \pm 29 \%)$ in both medium. Protein profile showed that all transgenic plants produced $45,8 \mathrm{kDa}$ protein and that was equivalent with molecular weight of KNAT1 protein. Taken together, all those data indicated that 35S::KNAT1 transgene were consistently integrated into the transgenic plant genome.
\end{abstract}

Keywords: 35S::KNAT1 (Knotted-Like Arabidopsis thaliana 1), multishoots, Phalaenopsis amabilis, transgene

\section{INTRODUCTION}

Orchid is an ornamental plant that has high economic value and high market sharing (da Silva 2013). Phalaenopsis amabilis (L.) Blume or known as moth orchid is an Indonesian native plants (Semiarti et al. 2007). P. amabilis commonly used as parental line for breeding purpose in terms to produce superior hybrid varieties (Semiarti et al. 2011a). P. amabilis is a monopodial orchid that having single growth node that emerging from the central part of a plant (Weissenhofer et al. 2013).

*Corresponding author: endsemi@ugm.ac.id; esemiart@gmail.com
For large scale propagation, monopodial orchid has many difficulties to meet the market demands since the orchid only has one single stem (Dresler 1981). The long periods of life cycle, 2-3 years, are also the emerging challenge in the cultivation of $P$. amabilis (Mercuriani et al. 2012). The damages of natural habitat and collection activities for commercial purposes are also significantly decline the amount of this orchid in nature (Weissenhofer etal.2013).

Genetic engineering using modified DNA is needed to obtain transgenic plants having better characters compared to its parental line. The KNAT1 gene (Knooted-like Arabidopsis thaliana 1) 
from Arabidopsis thaliana plant was successfully inserted into several plants i.e. in Rice (Sakamoto et al. 2006), P. amabilis (Semiarti et al. 2007), Celosia plumosus L(Sun et al. 2011). The BP/KNAT1 gene can be expressed in several spots in plants, but is primarily expressed in the region around the shoot apical meristem (SAM) and positively regulates SAM development in $A$. thaliana (Kerstetter \& Poethig 1998; Byrne et al. 2000). The expression of inserted transgene can be decreased by its growth condition and the series of repetitive subcultures. Based on that fact, the stability of the transgene function in the transformant needs to be observed. The aims of this study were: 1) to study integration existence in transgenic plants; 2) to observe the effect of auxin-cytokinin hormone in SIM medium; 3) to conduct protein profiling of transgenic $P$. amabilis harboring 35S::KNAT1 transgene. This research is important to maintain the continuous function of transgene in transformant plant.

\section{MATERIALS AND METHODS}

The study was conducted in the Laboratory of Plant Tissue Culture, Faculty of Biology and Genetic Engineering Laboratory of Biotechnology PAU UGM. This study used Phalaenopsis amabilis (L.) Blume (Java forms) which was inserted with 35S::KNAT1 by Semiarti et al. in 2007. The plant was maintained in in vitro conditions for seven generations before being used as material. The Code of transgenic plants was \# 7.121. Media used for the in vitro maintenance was New Phalaenopsis (NP), which was modified by Islam et al. (1998).

\section{Selection of Putative Transgenic in Medium Containing Kanamycin}

Resistance rate of the materials were observed in NP0 medium and shoot induction medium (NP SIM) added with Kanamycin as the selection agent. The concentration of Kanamycin added to the media was $200 \mathrm{ppm}$. Observations were made three times at the subculture to determine the increment of resistance to Kanamycin at each subculture. The subculture in those two media was observed for 12 weeks. Duration for three observations at the two subcultures was 36 weeks or 9 months. The usage of 200 ppm Kanamycin concentration was based on research conducted by $\mathrm{Yu}$ et al. (2001) who was successful in making selection to gain putative transgenic in orchidaceous plants, Dendrobium Madame ThongIn.

\section{Confirmation of KNAT1 gene co-integration into $P$. amabilis genome using PCR techniques}

The surviving plants in media containing 200 ppm Kanamycin selection agent was used in subsequent observations. Only plants that have survived in the last subculture were subjected into the confirmation of transgene integration, 35S::KNAT1. Plant DNA genome were isolated using CTAB 3\% methods (Saputro et al. 2016; Hasan et al. 2012) and then analyzed using PCR. PCR techniques were conducted using three primer pairs i.e. KNAT1 primers, NPTII primers and trnL-F primers. KNAT1 gene primer pairs, KNAT1F1 (5'-CCGAGAATTGCTTCCG ATCTG-'3) and KNAT1R1 (5'-CTTGAGT'T CCCGATCT'TCGGC-'3), NPTII gene primer pairs, NPTII F (5'-CACGACGGGCGTTCCT'T GC-'3), NPTIIR (5'-GTGGTCGAATGGGCA GGTAGC-'3), and universal primers for intergenic spacer trnL-F, trnL.e (5'GGTTCAAGTCCCTCTATCCC-'3) and trnL.f (5'-ATT'TGAACTGGTGACACGAG-'3). PCR were conducted using PCR thermocycler BOECO THERMAL CYCLER TC-SQ.

PCR performed with this following system: pre-denaturation at $94^{\circ} \mathrm{C}$ for 5 minutes, followed by 30 cycles of denaturation: annealing: extension $\left(94{ }^{\circ} \mathrm{C}\right.$ for 1 minute, $55^{\circ} \mathrm{C}$ for 1 minute and $72{ }^{\circ} \mathrm{C}$ for 2 minutes). The next stage was the post extension at $72{ }^{\circ} \mathrm{C}$ for 5 minutes and the final stage was cooling (hold) at $4{ }^{\circ} \mathrm{C}$ for 15 minutes. PCR products were then separated with $1 \%$ agarose gel electrophoresis, colored using Ethidium Bromide and visualized under UVtransluminator.

\section{Multiplication Rate of Transgenic Plant Harboring 35S::KNAT1 onto Medium NP0 and NP SIM}

The subculture plantlet in previous studies was divided based on its performance. Plants that were able to show the formation of multiple shoots were used as starting materials. 
Furthermore, the obtained materials were then planted onto NP0 and NPSIM media containing Kanamycin as the selection agent. The concentration of Kanamycin added into the media was $200 \mathrm{ppm}$. Subculture process was performed 3 times, 12 weeks each with total duration of 36 weeks or 9 months.

\section{Growth Patterns of Transgenic Plants harboring 35S ::KNAT1}

The observation of growth patterns were conducted by observing the formation of shoots in transgenic and non-transgenic plants. Nontransgenic plants were grown on NP0 and NP SIM media without Kanamycin; while transgenic plants were grown on NP0 and NP SIM media containing Kanamycin. Shoot formation was observed every two weeks to determine the average of shoot formation. Observations were made on the last subculture, performed on five non-transgenic and transgenic plants.

\section{Phenotypic Alteration in Transgenic Plants}

The population of putative transgenic plants obtained in the last subculture was classified based on their morphological variations. The classification of morphological variation was based on the shape change of plant organs compared with non-transgenic plants. The observation of variation was separated based on grown medium.

The Effect of KNAT1 Genes into the Alteration of Venation Pattern of Transgenic Plants

The first leaves of non-transgenic and transgenic Phalaenopsis amabilis were fixed in a mixture of $14 \%$ glacial acetic acid $\left(\mathrm{CH}_{3} \mathrm{COOH}\right)$ : $84 \%$ ethanol $\left(\mathrm{C}_{2} \mathrm{H}_{5} \mathrm{OH}\right)$ solution. The leaves were then incubated overnight at room temperature. The specimens were then dehydrated twice in 70\% ethanol (1 hour for each dehydration) and twice in 99.5\% ethanol (1 hour for each dehydration). Furthermore, the specimen was immersed overnight in a mixture of chloral hydrate clearing solution $\left(\mathrm{C}_{2} \mathrm{H}_{3} \mathrm{Cl}_{3} \mathrm{O}_{2}\right)$. Leaf specimens were finally observed under an ESCHENBACH microscope with 20x magnification (Berleth \& Jurgen 1993).

\section{Protein Profile Analysis of 35S::KNAT1 Transgenic Plants using SDS-PAGE}

Phalaenopsis amabilis leaves were cut. Leaves sample was determined to be $150 \mathrm{mg}$. The samples were added with $200 \mathrm{~mL}$ PBS and finely ground until homogen. All homogenates were collected and then put into a sterile tube. Homogenates were centrifuged at 6000G for 5 minutes. The supernatant was transferred into a new sterile tube and stored at $4{ }^{\circ} \mathrm{C}$. Protein profile of plants were analyzed using SDS-PAGE (Holme \& Peck 1998).

\section{RESULTS AND DISCUSSION}

\section{Selection of Putative Transgenic in Medium Containing Kanamycin}

The selection process to ensure the candidate of transgenic plants was conducted by growing all candidates in NP0 and NP SIM media containing 200 ppm Kanamycin. Detail information of the resistance is shown in Table 1 . The data indicated that the percentage of surviving plants were improved along the subculture process.

Table 1 Resistance level of transgenic P. amabilis and non-transgenic P. amabilis toward Kanamycin after 12 weeks observation

\begin{tabular}{|c|c|c|c|c|}
\hline \multirow{3}{*}{ Phase } & \multicolumn{4}{|c|}{ Resistance toward Kanamycin (\%) } \\
\hline & \multicolumn{2}{|c|}{ NP0 } & \multicolumn{2}{|c|}{ NP SIM } \\
\hline & $\begin{array}{c}\text { Non } \\
\text { Transgenic }\end{array}$ & Transgenic & $\begin{array}{c}\text { Non } \\
\text { Transgenic }\end{array}$ & Transgenic \\
\hline $8^{\text {th }}$ Subculture & 0 & 17.95 & 0 & 15.38 \\
\hline $9^{\text {th }}$ Subculture & 0 & 48.15 & 0 & 46.88 \\
\hline $10^{\text {th }}$ Subculture & 0 & 58.70 & 0 & 62.50 \\
\hline
\end{tabular}


The resistance of putative transgenic in media containing Kanamycin were caused by expression of selectable marker gene i.e. NPTII gene. The increment of plant resistance to Kanamycin is shown in Table 1.

Confirmation of Transgene 35S::KNAT1 Cointegration on the P. amabilis Genome using PCR Technique

trnL-F amplicon was produced in all lines (Fig. 1). Line $A$ and $B$ were the example of control (non-transgenic plants). Line $\mathrm{C}$ and $\mathrm{D}$ were transgenic plants having only NPTII gene attached on its genome. Line $\mathrm{E}$ and $\mathrm{F}$ had three
DNA fragments i.e. 200 bp (NPTII gene), 500 bp (trnL-F intergenic spacer) and $616 \mathrm{bp}$ of KNAT1 gene. These plants considered as putative transgenic. The putative transgenic having those three bands was determined as positive transformant. Detail percentage of positive transformant is shown in Table 2.

The co-integration percentage was shown in Table 2. The non-transgenic plants were used as a control and showed zero percentage of cointegration. The highest percentage of $93.33 \%$ were obtained by putative transgenic grown in NP SIM. Co-integration percentage of putative transgenic planted onto NP0 medium was only $85.50 \%$.

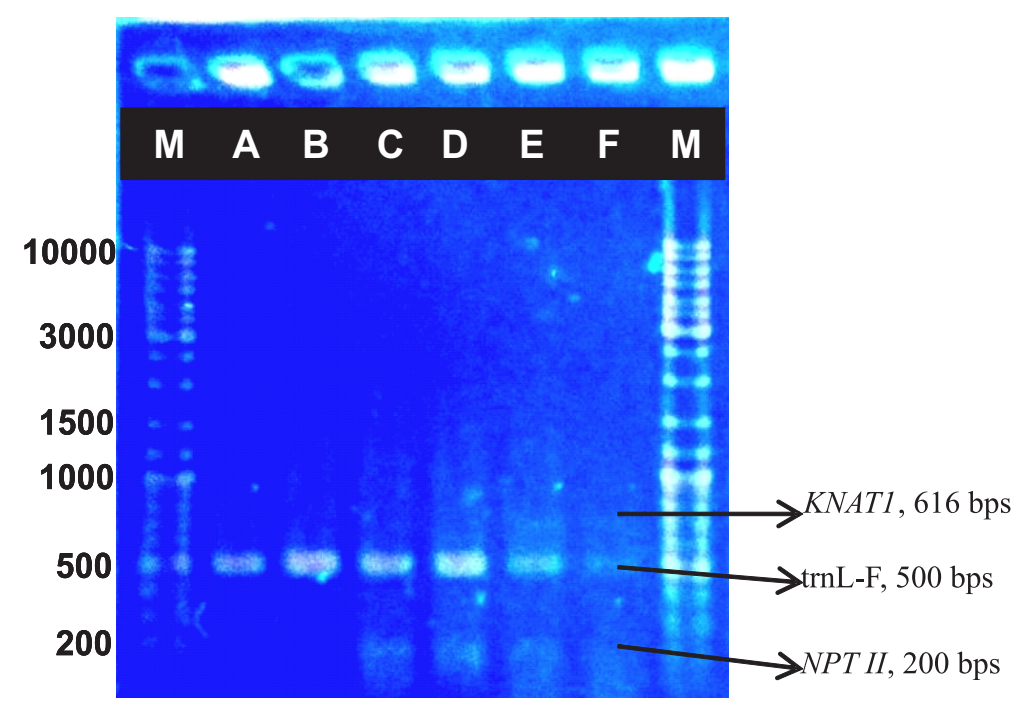

Figure 1 Electrophoregrams of PCR result: $\mathrm{M}=$ Gene ruler of DNA Ladder Mix; A-B = non-transgenic of P. amabilis; $\mathrm{C}-\mathrm{D}=$ fragment of NPTII gene; $\mathrm{E}-\mathrm{F}=$ positive transgenic

Table 2 Co-integration percentage of 35::KNAT1 transgene into P. amabilis chromosomes

\begin{tabular}{|c|c|c|c|c|c|}
\hline \multirow[b]{2}{*}{ Plants } & \multirow[b]{2}{*}{ Medium } & \multicolumn{3}{|c|}{ Genotype character } & \multirow{2}{*}{$\begin{array}{c}\text { Co-integration } \\
\text { percentage } \\
(\%)\end{array}$} \\
\hline & & $\operatorname{trnL}-\mathrm{F}$ & $\begin{array}{l}\text { trnL-F, } \\
\text { NPTII }\end{array}$ & $\begin{array}{c}\text { trnL-F, } \\
\text { NPTII, KNAT1 }\end{array}$ & \\
\hline \multirow[t]{2}{*}{ Non transgenic } & NP0 & 10 & 0 & 0 & $\begin{array}{c}0 / 10 \\
(0.00 \%)\end{array}$ \\
\hline & NP SIM & 10 & 0 & 0 & $\begin{array}{c}0 / 10 \\
(0.00 \%)\end{array}$ \\
\hline \multirow[t]{2}{*}{ Putative transgenic } & NP0 & 40 & 7 & 33 & $\begin{array}{c}33 / 40 \\
(82.50 \%)\end{array}$ \\
\hline & NP SIM & 30 & 2 & 28 & $\begin{array}{c}28 / 30 \\
(93.33 \%)\end{array}$ \\
\hline
\end{tabular}


Multiplication Rate of Transgenic Plant 35S::KNAT1 onto NP0 and NPSIM Media

Shoot Apical Meristem (SAM) requires a high concentration of cytokinin and low concentration of gibberellin to maintain its growth and meristematic function to continuously produce indeterminate organs. This condition can be achieved by introducing KNAT1 gene. Results of this study showed that transgenic plants remained to have high stability in the $10^{\text {th }}$ subculture.

The stabilizing function of transgen in transformant can be observed by its ability to produce multi shoots. The multiplication rate of $P$. amabilis (transgenic or non-transgenic) was relatively higher when planted onto SIM medium compared to NP0 medium. The amount of shoots formation is shown in Table 3. NP SIM medium provided higher shoot formation compared to NP0 medium. Transgenic plants also provided higher shoots formation compared to non-transgenic plants.

Transformant planted in NP0 medium showed $398 \%$ in multiplication rate, while transformant planted in NP SIM showed higher rate (567\%). Those results indicated that cytokinin-added medium was more suitable to provide large amount of positive transformant. Statistical analysis showed that NP SIM medium was significantly provided higher shoot formation compared to NP0 medium. Transgenic plants also provided higher shoots formation compared to non-transgenic plants. Furthermore, the combination of those two factors did not show any interactions in increasing the shoots formation.

\section{Growth Pattern in Transgenic Plant Harboring 35S::KNAT1}

Plants inserted with 35S::KNAT1 produced earlier shoots compared to the non-transgenic plants (Table 4). In transgenic plant, the shoots were already formed in four weeks after planting, while the non-transgenic plants started to produce shoot in six weeks after planting. In NP SIM medium, the addition of new shoots was higher than in NP0 medium.

Table 3 Shoot formation of P. amabilis within three subcultures

\begin{tabular}{|c|c|c|c|c|c|c|}
\hline \multirow[b]{2}{*}{ Plants } & \multirow[b]{2}{*}{ Medium } & \multirow{2}{*}{$\begin{array}{l}\text { Number } \\
\text { of planted } \\
\text { explants }\end{array}$} & \multicolumn{4}{|c|}{ After } \\
\hline & & & $\begin{array}{l}\text { Number of } \\
\text { dead plants }\end{array}$ & $\begin{array}{c}\text { Number of } \\
\text { surviving } \\
\text { plants }\end{array}$ & $\begin{array}{l}\text { Number } \\
\text { of shoots }\end{array}$ & $\begin{array}{c}\text { Multiplication } \\
\text { rate }(\%)\end{array}$ \\
\hline \multicolumn{7}{|l|}{$8^{\text {th }}$ Subculture } \\
\hline \multirow[t]{2}{*}{ Non-transgenic } & NP0 & 30 & 0 & 30 & 30 & 100.00 \\
\hline & NP SIM & 30 & 0 & 30 & 49 & 163.33 \\
\hline \multirow[t]{2}{*}{ Putative transgenic } & NP0+Kanamycin & 39 & 32 & 7 & 27 & 385.71 \\
\hline & NP SIM+Kanamycin & 39 & 33 & 6 & 32 & 533.33 \\
\hline \multicolumn{7}{|l|}{$9^{\text {th }}$ Subculture } \\
\hline \multirow[t]{2}{*}{ Non-transgenic } & NP0 & 30 & 0 & 30 & 30 & 100.00 \\
\hline & NP SIM & 30 & 0 & 30 & 62 & 206.67 \\
\hline \multirow[t]{2}{*}{ Putative transgenic } & NP0+Kanamycin & 27 & 14 & 13 & 54 & 415.38 \\
\hline & NP SIM+Kanamycin & 32 & 17 & 15 & 83 & 553.33 \\
\hline \multicolumn{7}{|l|}{$10^{\text {th }}$ Subculture } \\
\hline \multirow[t]{2}{*}{ Non-transgenic } & NP0 & 30 & 0 & 30 & 33 & 110.00 \\
\hline & NP SIM & 30 & 0 & 30 & 53 & 176.67 \\
\hline \multirow[t]{2}{*}{ Putative transgenic } & NP0+Kanamycin & 46 & 19 & 27 & 106 & 392.59 \\
\hline & NP SIM+Kanamycin & 24 & 9 & 15 & 74 & 493.33 \\
\hline
\end{tabular}


Table 4 Shoot formation of $P$. amabilis

\begin{tabular}{|c|c|c|c|c|c|c|c|c|}
\hline \multirow{2}{*}{ Plants } & \multirow{2}{*}{ Medium } & \multirow{2}{*}{$\begin{array}{c}\text { Numbe } \\
\text { r of } \\
\text { shoots }\end{array}$} & \multicolumn{6}{|c|}{ Number of new shoots in weeks after planting } \\
\hline & & & 0 & 2 & 4 & 6 & 8 & 10 \\
\hline \multirow[t]{2}{*}{ Non-transgenic } & NP0 & 5 & 0 & 0 & 0 & 0 & 0 & 0 \\
\hline & NP SIM & 5 & 0 & 0 & 0 & 1 & 1 & 1 \\
\hline \multirow[t]{2}{*}{ Transgenic } & $\mathrm{NP} 0+$ Kanamycin & 5 & 0 & 0 & 1 & 2 & 2 & 3 \\
\hline & NP SIM+Kanamycin & 5 & 0 & 0 & 2 & 3 & 4 & 4 \\
\hline
\end{tabular}

KNAT1 gene was isolated from Arabidopsis thaliana plant. KNAT1 gene is expressed in Shoot Apical Meristem (Jackson et al. 1994) which is the indeterminate organ. KNAT1 genes are down regulated when leaf initiation process occurrs. These expression pattern describes the important role of KNAT1 gene to maintain an indeterminate form of meristem and repressing the differentiation process (Byrne et al. 2000). KNAT1 gene was inserted in P. amabilis under the control of $35 \mathrm{~S}$ strong promoter from Cauliflower Mozaic virus (CaMV) causing the occurrence of over-expression of KNAT1 gene.

Over-expression of KNAT1 gene in Arabidopsis was known to cause the formation of new shoots on upper and lower surfaces of Arabidopsis leaves, an alternation of the normal leaf shapes into lobed shape (Lincoln et al. 1994; Chuck et al. 1996) as well as in tobacco plants (Nishimura et al. 2000). Insertion of KNAT1 gene into $P$. amabilis was expected for further observation about the function of KNAT1 gene and its influence on the shoot growth. The multiplication level of shoots is shown in Figure 2. There was only one shoot formed in nontransgenic plants, while the transgenic plants were able to produce multishoots.

\section{Phenotypic Alteration in Transgenic Plants}

Over-expression of KNAT1 gene leads to many changes in plant phenotype. Overexpression of KNAT1 gene causes leaf alteration, ectopic meristems, inflorescence-like structures formation, dwarfishness, apical dominance loss and generation of meristematic tissues in leaf (Williams-Carrier et al. 1997; Sun et al. 2011). The usage of KNAT1 gene as a selectable marker was successfully conducted by Luo et al. (2006).

In this study, an interesting phenomenon was also found i.e. six alterations of plant morphology occurred in plants inserted with KNAT1 gene. Those six alternations were

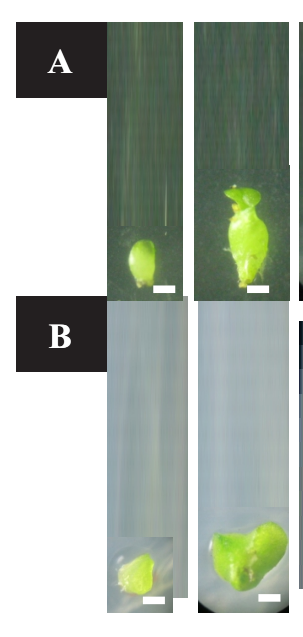

24

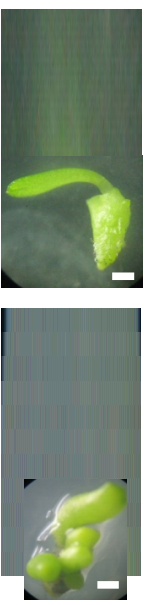

6

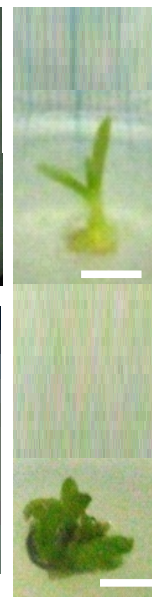

8

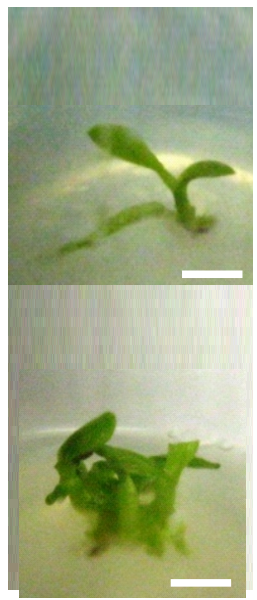

10

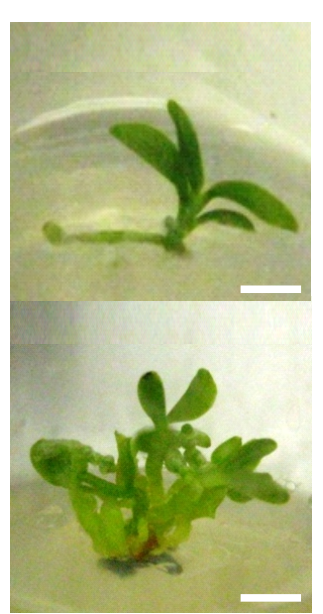

12

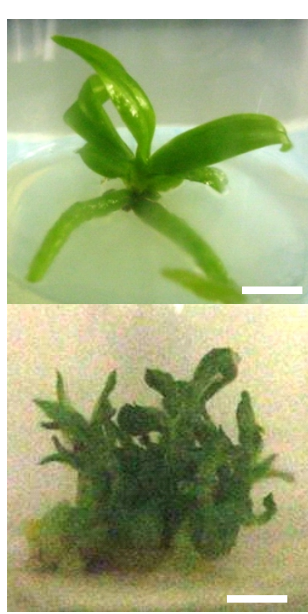

16

Figure 2 Growth pattern in shoot formation of Phalaenopsis amabilis 16 weeks after planting: A. Non-transgenic plants; B. Transgenic plants using 35S::KNAT1 (scale for $2-6$ weeks $=1 \mathrm{~mm}$; scale for $8-16$ weeks $=0.5 \mathrm{~cm}$ ) 
normal leaves, lobed leaves, rosette, elongated stem, cup-shoot and widened leaves. In this study, the normal leaves was the most abundant variants found. It is important to obtain information whether the alterations are inherited in $P$. amabilis progenies. In lettuce plants (Frugis et al. 2001 ) and Celosia plumosus (Sun et al. 2011), the harboring KNAT1 gene were reported to inherit morphological alteration of the first generation of transformant plants (T0). The selfing results showed that $75 \%$ of filial (T1) denoting the alteration in the shape of its first leaf, but not changing the percentage of seed germination, the emergence time of the first leaf and its phylotaxis (Frugis et al. 2001). All the variations in this research were caused by the over-expression of 35S::KNAT1 (Tabel 5).

Venation patterns of non-transgenic and transgenic plants were observed to ensure the anatomic performance of leaves. The results showed that the alteration also occurred in the venation of leaf (Fig. 3). The alterations were detected from the very early stage of leaf development. The over-expression of KNAT1 gene are able to disturb hormon concentration in SAM leading to imbalance status. The details of alteration occurred every two weeks are shown in Figure.3. In lobed leaves variant, the venation pattern was also shown. The results showed that there was a fundamental change concerning the

Table 5 Percentage of morphological variation in P. amabilis transgenic 35S::KNAT1

\begin{tabular}{|c|c|c|c|c|c|c|c|}
\hline \multicolumn{7}{|c|}{ Plant phenotype } & \\
\hline Variations & $\begin{array}{c}\text { Number of } \\
\text { plants }\end{array}$ & Normal (\%) & $\begin{array}{c}\text { Lobed } \\
\text { leaves } \\
(\%) \\
\end{array}$ & $\begin{array}{c}\text { Rosette } \\
(\%)\end{array}$ & $\begin{array}{c}\text { Elongated } \\
\text { stem } \\
(\%) \\
\end{array}$ & $\begin{array}{c}\text { Cup shoot } \\
(\%)\end{array}$ & $\begin{array}{c}\text { Widened } \\
\text { leaves } \\
(\%) \\
\end{array}$ \\
\hline NP0 & 106 & 29.25 & 11.32 & 14.15 & 9.43 & 19.81 & 16.04 \\
\hline NP SIM & 74 & 29.73 & 13.51 & 12.16 & 9.46 & 29.73 & 5.41 \\
\hline
\end{tabular}
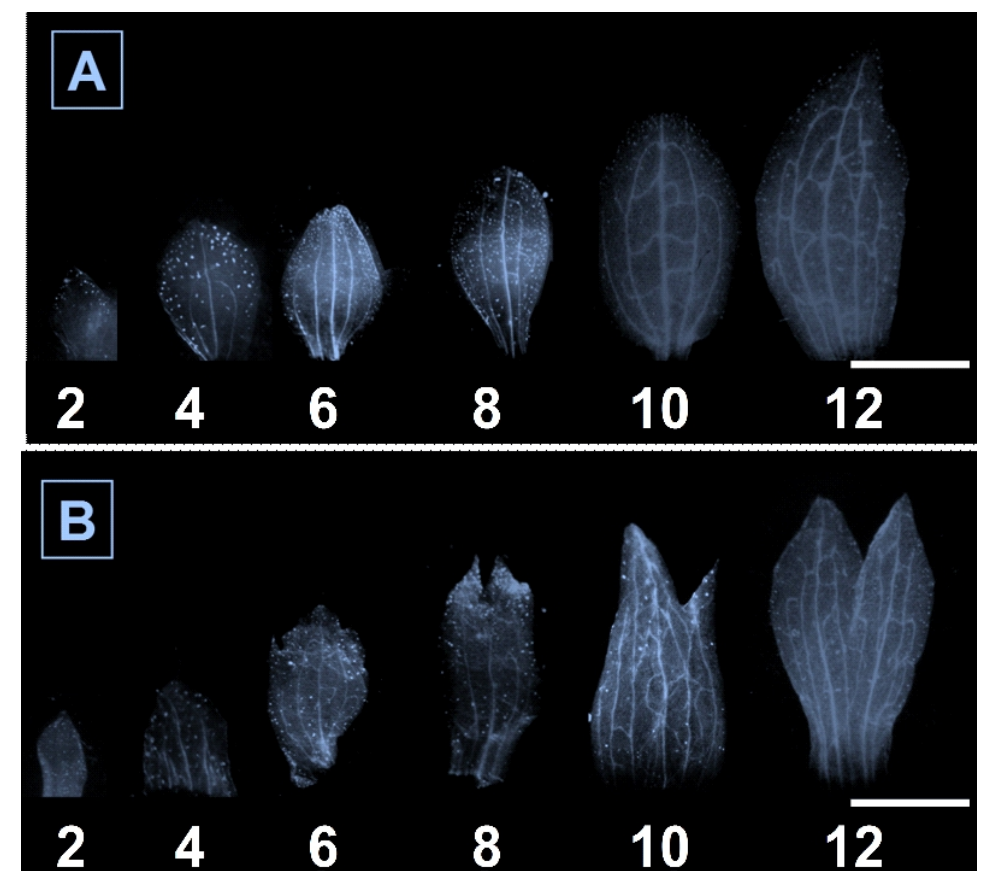

Figure 3 The differentiation of leaf venation patterns observed in 2, 4, 6, 8, 10, and 12 weeks: A. Regular (normal) venation of leaf; B. Irregular venation (scale $=0.5 \mathrm{~cm}$ ) 


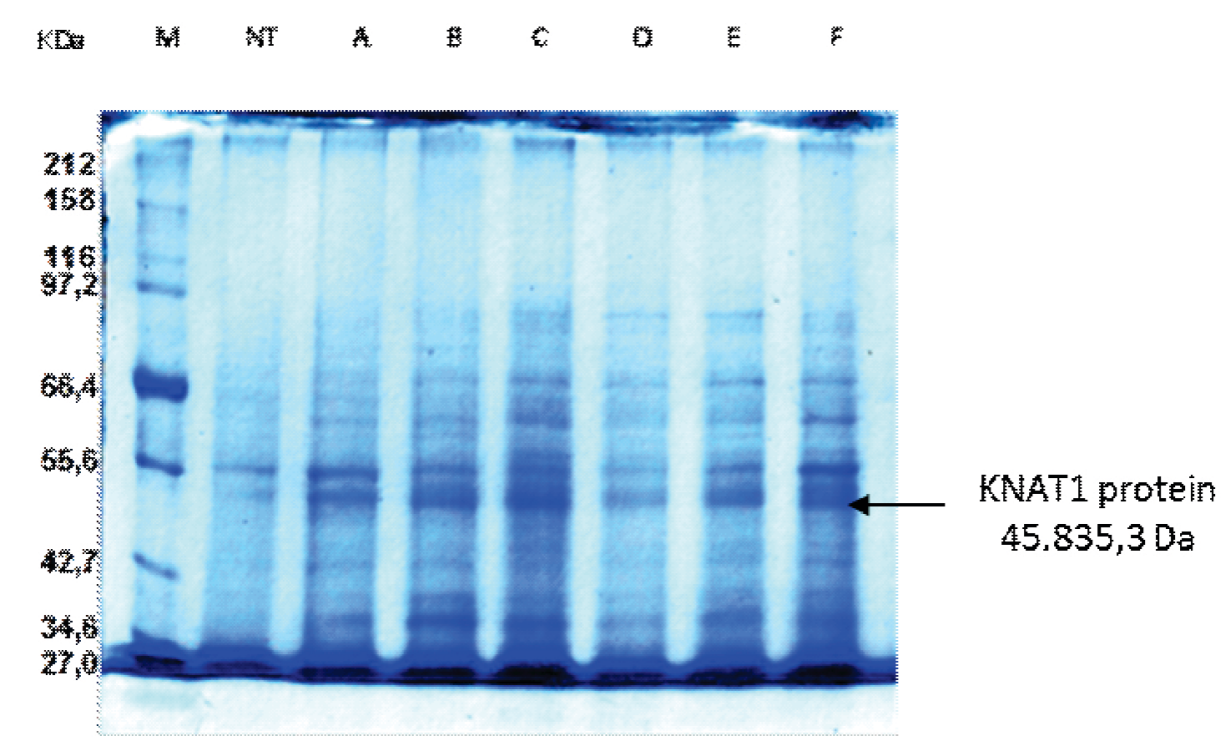

Figure 4 Electrophoregrams of $P$. amabilis protein profile: $\mathrm{M}=$ protein marker, broad range, Biolabs; $\mathrm{NT}=\mathrm{Non}$ transgenic; $\mathrm{A}=$ normal variant of transgenic plants; $\mathrm{B}=$ lobed leaves; $\mathrm{C}=$ rossete; $\mathrm{D}=$ elongated stem; $\mathrm{E}=$ widened leaves; $\mathrm{F}=$ cup shoot

development of leaf vascularization compared to non-transgenic plants. The appearance of lobus in leaf's lamina causes the irregular venation. Furthermore, in severe level, the alterations produce the emergence of two mid-vein in one leaf's lamina.

\section{Protein Profile Analysis of 35S::KNAT1 Transgenic Plants using SDS-PAGE}

Materials used in this profiling is the proven materials that carry KNAT1 gene and represents various types of morphological variants. KNAT1 protein contains 398 amino acids with 45,835.3 Daltons. One hundred percent of tested plants all had bands of $45 \mathrm{kDa}$ in size indicating KNAT1 protein (Fig. 4). Different intensity was caused by $P$. amabilis growth phase.

\section{Co-integration Analysis of 35S::KNAT1 Transgen into Phalaenopsis amabilis Genome}

The material used in this study is Phalaenopsis amabilis orchid which had been transformed with plasmid containing the construction of KNAT1 cDNA gene (Knooted-like Arabidopsis thaliana 1). Transformation of 35S::KNAT1 on Moth orchid mediated by Agrobacterium tumafaciens was established by Semiarti et al. (2011b). The results of regeneration showed that not all of plants are positive transgenic plants harboring $35 \mathrm{~S}:$ :KNAT1 in their genome. This phenomenon can be caused by many factors. Among others, chimera is the main factor causing diversity in plant genome. Chimera may occur in the transformation because not the whole plant cells are being infected by Agrobacterium tumafaciens during co-cultivation. Chimera can be reduced by conducting repetitive subcultures on selection medium.

Selection marker gene which is often used in the plasmid construction is an antibiotic resistance gene or herbicide resistance gene. The selection marker gene that were used in the plasmid construction in this purpose is an antibiotic resistance gene, NPTII (Neomycin Phosphotransferase) gene. NPT gene showed high resistance over Kanamycin antibiotic. Kanamycin gene expression lead a transgenic $P$. amabilis to have a survival performance in the medium containing Kanamycin, while non transgenic plants could not survive. The surviving plants in antibiotic selection medium were isolated using its genome DNA and subjected to PCR. The results obtained from PCR showed that not all surviving plants on selection medium was transgenic plants harboring 35S::KNAT1, sometimes only harboring NPTII gene.

Plants carry only the antibiotic resistance genes because the plants have defense mechanisms that prevent the introduction of foreign objects. When infected to the plant cells, T-DNA was protected by the complex of VirE2 and VIP1 (VirE2 Protein Interacting). The 
integration process requires T-DNA in free condition which means that T-DNA does not form a complex with VirE2 and VIP1. The VirE2 and VIP1 need to be eliminated first. VirE2 Protein is required in the T-DNA transfer process (Rossi et al. 1996). Plants activates the F-box proteins associated with the defense i.e. VBF (VIP1-F-box binding protein). VBF protein makes the complex VirE2 and VIP1 becomes unstable through the mechanism of proteosom degradation mediator by SCF mediator (Skp, Cullin, F-box containing complex).

The ideal mechanism to eliminate the VirE2 and VIP protein occurs when T-complex is already approach the target chromatins. On the other hand, when the elimination process occurs just before T-complex approaches the chromatin, the transient expression and T-DNA degradation by nuclease and several part of those construction gene are integrated into plants genomes (Zaltsman et al. 2010).

Protein profile of transgenic plants indicates that protein with molecular weight of $45.8 \mathrm{KDa}$ exists. This protein is predicted as KNAT1 protein. The results showed that all transformant plants were able to produce KNAT1 protein. Non-transformant plants were unable to produce KNAT1 protein. KNAT1 protein is a transcription factor for plant growth, so the high amount of KNAT1 protein changes the hormonal balance in SAM region. SAM plays a dynamic and pivotal role in guiding plant growth. The disproportion of hormonal concentration may lead to morphological alteration in transformant plant. Hormone concentration was regulated in the synthesis process, transport and conversion into a more or less active form (Veit 2009).

Auxin, gibberellin and cytokinin together are known as the hormones having key role in determining plant morphology. Auxin and gibberellin are the mandatory hormones mediating the formation of lateral organs or determinate organs. Cytokinin has contrary activities and associated with indeterminate growth programs of cells, including maintaining the number of indeterminate cell population in SAM. The center region of SAM has relatively low concentration of GA caused by high concentration of KNAT1 protein which represses gene transcription encoding GA20 oxidase (Hay et al. 2002). Bolduc and Hake (2009) concluded that the regulator elements in the near 3' end of first introns of GA2OX1 gene binded by $\mathrm{KN} 1$ in maize. KNOX proteins on tobacco plants, NTH15 protein can directly suppress the transcription of the Ntc12 gene, which is the gene that encodes GA20-oxidase required in GA biosynthesis (Sakamoto et al. 2001).

KNAT1 gene activity in the central zone of SAM is able to increase the concentration of cytokinin. The increment of cytokinin due to KNOX protein is capable to activate isopentenyl transferase genes. Isopentenyl transferase involves in catalyzing a step in the cytokinin biosynthesis. Higuchi et al. (2004) reported that the over-expression of gene that encoding cytokinins oxidase can decrease cytokinins concentrations in cells. This condition leads to the reduction of meristem size and is able to initiate the formation of leaf and other tissues. On the other hand, in several cases, the decrement of endogenic cytokinins level causes meristem abortion (Werner et al. 2003). KNOX protein is the main regulators controlling hormonal balance, either at dicotyls or monocotyls plants (Sakamoto et al. 2006; Hay et al.2002).

\section{CONCLUSIONS}

35S::KNAT1 transgene was consistently integrated with Phalaenopsis amabilis genome until the $10^{\text {th }}$ subculture. There were many alterations in plant morphology classified into six main groups: normal, lobed leaves, rossete, elongated stem, cup shoot and widened leaves. The plant morphology was dominated by normal variant. All transgenic plants harboring 35S::KNAT1 produced protein with molecular weight of 45.8 $\mathrm{Kda}$, equivalent with KNAT1 protein size. It is important to have confirmation on amino acids sequence to ensure whether it is the KNAT1 protein. It is suggested that further confirmation is required for transgene expression at the $\mathrm{mRNA}$ to determine the level of transcription in every transgenic plant lines harboring 35S:: KNAT1.

\section{REFERENCES}

Berleth T, Jürgens G. 1993. The role of the monopteros gene in organising the basal body region of the Arabidopsis embryo. Development 118:575-87. 
Bolduc N, Hake S. 2009. The maize transcription factor KNOTTED1 directly regulates the gibberellin catabolism gene GA2OX1. The Plant Cell Preview: $1-12$.

Byrne ME, Barley R, Curtis M, Arroyo JM, Dunham M, Hudson A, Martienssen RA. 2000. Asymmetric leaves1 mediates leaf patterning and stem cell function in Arabidopsis. Nature 408:967-71.

Chuck G, Lincoln C, Hake S. 1996. KNAT1 induced lobed leaves with ectopic meristem when overexpressed in Arabidopsis. Plant Cell 8:1277-89.

Dressler RL. 1981. The orchid: Natural history and classification. Harvard (US): Harvard University press.

Frugis G, Giannino D, Mele G, Nicolodi C, Chiappetta A, Bitonti MB, ... Mariotti D. 2001. Over-expression of KNAT1 in lettuce shift leaf determinate growth to a shoot-like indeterminate growth associated with an accumulation of isopentenyl type cytokinins. Plant Physiol 126:1370-80.

Hasan S, Prakash J, Vashishtha A, Sharma A, Srivastava K, Sagar F, ... Mishra S. 2012. Optimization of DNA extraction from seeds and leaf tissues of Chrysanthemum (Chrysanthemum indicum) for polymerase chain reaction. Bioinformation 8(5):2258.

Hay A, Kaur H, Phillips A, Hidden P, Hake S. 2002. The gibberellin pathway mediates Knotted1-Type Homeobox function in plants with different body plans. Curr Biol 12:1557-65.

Higuchi M, Pischke MS, Mahonen AP, Miyawaki K, Hashimoto Y, Seki M, ... Kakimoto T. 2004. In planta functions of the Arabidopsis cytokinin receptor family. PNAS 101:8821-6.

Holme DJ, Peck H. 1998. Analytical biochemistry, third edition. New York (US): Addision Wesley Longman.

Islam MO, Ichihashi S, Matsui S. 1998. Control of growth and development of protocorm like body derived from callus by carbon sources in Phalaenopsis. Plant Biotechnol J 15:183-7

Jackson D, Veit B, Hake S. 1994. Expression of maize KNOTTED1 related homeobox genes in the shoot apical meristem predicts patterns of morphogenesis in the vegetative shoot. Development 120:405-13.

Kerstetter RA, Poethig RS. 1998. The specification of leaf identity during shoot development. Annu Rev Cell Dev Biol 14:373-98.

Lincoln C, Long J, Yamaguchi J, Sarikawa, Hake S. 1994. A Knotted1-like homeobox gene in Arabidopsis is expressed in the vegetative meristem and dramatically alters leaf morphology when overexpressed in transgenic plants. Plant Cell 6:1859-76.

Luo K, Zheng X, Chen Y, Xiao Y, Zhao D, McAvoy R, ... Li Y. 2006. The maize Knotted1 gene is an effective positive selectable marker gene for Agrobacteriummediated tobacco transformation. Plant Cell Rep 25:403-9.

Mercuriani IS, Purwantoro A, Moeljopawiro S, Semiarti E. 2012. Insertion of a Flowering Gene, PaFT, into Phalaenopsis amabilis Orchid using Agrobacterium tumefaciens. Proceeding of the $5^{\text {th }}$ Indonesia Biotechnology Conference. An International Forum. p. 152-161.

Nishimura A, Tamaoki M, Sakamoto T, Matsuoka M. 2000. Over-expression of tobacco Knotted1-type class1 homeobox genes alters various leaf morphology. Plant Cell Physiol 41:583-90.

Rossi L, Hohn B, Tinland B. 1996. Integration of complete transferred DNA units is dependent on the activity of virulence E2 protein of Agrobacterium tumefaciens. Proceedings of the National Academy of Science 93:126-30

Sakamoto T, Kamiya N, Ueguchi-Tanaka M, Iwahori S, Matsuoka M. 2001. KNOX homeodomain protein directy suppresses the expression of a gibberellin biosynthetic gene in the tobacco shoot apical meristem. Genes Dev 15:581-90.

Sakamoto T, Sakakibara H, Kojima M, Yamamato Y, Nagasaki H, Inukai Y, ... Matsuoka M. 2006. Ectopic expression of Knotted1-like Homeobox protein induces expression of cytokinin biosynthesis genes in rice. Plant Physiol 142:54-62.

Saputro TB, Finariyah F, Dianawati S, Sholihah NF, Ermavitalini D. 2016. In Vitro selection of local maize (Zea mays) on $\mathrm{NaCl}$ stress and its genetic characterization using RAPD. Biosaintifika $8(3): 344-51$.

Semiarti E, Indrianto A, Purwantoro A, Isminingsih S, Suseno N, Ishikawa T, ... Machida C. 2007. Agrobacterium-mediated transformation of the wild orchid species Phalaenopsis amabilis. Plant Biotechnol 24:265-72.

Semiarti E, Indrianto A, Purwantoro A, Machida Y, Machida C. 2011a. Agrobacterium-mediated transformation of Indonesian orchids for micropropagation, genetic transformation. In: Alvarez $M$, editor. Available from: http://www.intechopen.com/books/genetictransformation/agrobacterium-mediatedtransformation-of-indonesian-orchids-formicropropagation.

Semiarti E, Indrianto A, Purwantoro A, Martiwi INA, Feroniasanti YML, Nadifah F, ... Machida C. 2011b. Establishment of high-frequency genetic transformation method of Indonesian orchid species mediated by Agrobacterium tumefaciens. Proceedings of NIOC.

da Silva JAT. 2013. Orchids: Advances in tissue culture, genetics, phytochemistry and transgenic biotechnology. Floriculture Ornamental Biotech 7(1):1-52. 
Sun SB, Song JP, Yang J. 2011. Over-expressing Arabidopsis KNAT1 gene in Celosia plumosus L. causes modification of plant morphology. Acta Physiol Plant 33:1597-602.

Veit B. 2009. Hormone mediated regulation of the shoot apical meristem. Plant Mol Biol 69: 397-408.

Weissenhofer A, Huber W, Weber A, Wanek W, Gegenbauer C, Rakosy D, ... Speckmaier M. 2013. Orchids: Botanical jewels of the Golfo Dulce region, Costa Rica. Vienna (AT): Verein zur Förderung der Tropenstation La Gamba.

Werner T, Motyka V, Laucou V, Smets R, van Onckelen H, Schmulling T. 2003. Cytokinin-deficient transgenic Arabidopsis plants show multiple developmental alterations indicating opposite functions of cytokinins in the regulation of shoot and root meristem activity. Plant Cell 15:2532-50.

Williams-Carrier RE, Lie YS, Hake S, Lemaux PG. 1997. Ectopic expression of the maize KN1 gene phenocopies the hooded mutant of barley. Development 124:3737-45.

Yu H, Yang SH, Goh CJ. 2001. Agrobacterium-mediated transformation of a Dendrobium orchid with class1 KNOX Gene DOH1. Plant Cell Rep 20:301-5.

Zaltsman A, Krichevsky A, Kozlovsky SV, Yasmin F, Citovsky V. 2010. Plant defense pathways subverted by Agrobacterium for genetic transformation. Plant Signal Behav 5:1245-8. 